\title{
A study of biochemical parameters and microbial organisms in ascitic fluid of spontaneous bacterial peritonitis patients
}

\author{
Gadekar $\mathbf{R}^{1}$, Tyagi $\mathrm{A}^{2}$, Waran $\mathbf{M}^{3}$, Srivastava $\mathrm{AK}^{4}$ \\ ${ }^{1}$ Dr Rahul Gadekar, Associate Professor, ${ }^{2}$ Brig (Dr) Arun Tyagi, Professor \& HOD, ${ }^{3}$ Dr Marcia Waran, Professor, ${ }^{4}$ Brig \\ (Dr)A.K.Srivastava, Associate Professor, Department of Medicine, DVVPF's, Medical College, Ahmednagar, \\ Maharashtra, India.
}

Corresponding Author: Brig (Dr) Arun Tyagi, Professor \& HOD, Department of Medicine, DVVPF's Medical College, Vadgaon Gupta, Post- MIDC, Ahmednagar (Maharashtra).Email: aruntyagidr@gmail.com

\begin{abstract}
Introduction: Spontaneous Bacterial Peritonitis (SBP) is recognized as a severe complication in patients of ascites. In recent years, it has also been diagnosed in patients without liver disease. SBP is commonly reported in patients of ascites due to cirrhosis of liver. If untreated, SBP could be a fatal complication in patients of ascites. Objective: To study the biochemical parameters and causative micro-organisms in ascitic fluid patients in suffering from SBP. Materials and Methods: A prospective study was performed on 100 patients of ascites out of which 68 were males and 32 were females. After admission all patients were interviewed and detailed history taken and complete physical examination was performed. Results: In this study $86.7 \%$ patients had increased serum bilirubin levels, $73.4 \%$ patients had decreased serum albumin, $46.7 \%$ and $40 \%$ patients had increased blood levels of urea and creatinine respectively. $60 \%$ patients had ascitic fluid $\mathrm{pH}<7.30$ while $80 \%$ patients had ascitic fluid proteins $<1 \mathrm{gm} / \mathrm{dl}$. All patients had $>250$ polymorphonuclear cells $/ \mu \mathrm{L}$ and $80 \%$ patients had $>500$ polymorphonuclear cells $/ \mu \mathrm{L}$ in ascitic fluid. $46.7 \%$ cases of SBP were culture positive and $53.3 \%$ were culture negative.Gram staining of ascitic fluid was positive in one case. Conclusion: Hypoalbuminemia, hyperbilirubinemia, low ascitic fluid $\mathrm{pH}$, low ascitic fluid proteins, increased blood urea and creatinine levels are risk factors related with development of SBP in patients of ascites. The commonest micro-organism identified on culture were E-coli.
\end{abstract}

Key words: Spontaneous Bacterial Peritonitis, Ascitic Fluid, Causative, Organisms, Biochemical Parameters

\section{Introduction}

Ascites refers to accumulation of fluid in the peritoneal cavity. Its presence can usually be established by clinical examination but in doubtful cases, ultrasound may be helpful. Contributory pathogenic factors include increased portal venous pressure, decreased plasma oncotic pressure, increased hepatic lymph formation and secondary hyperaldosteronism [1].

Ascitic fluid may get infected spontaneously or as a result of gut perforation, intra-abdominal abscess, previous paracentesis. Primary abdominal infection due to bacteremia in the absence of an obvious intraabdominal focus of infection is known as spontaneous bacterial peritonitis (SBP) [2]. SBP is recognized as a severe complication in patients of ascites.It was initially described in patients of end stage liver disease. But in

Manuscript received: $10^{\text {th }}$ August 2018

Reviewed: $20^{\text {th }}$ August 2018

Author Corrected: $26^{\text {th }}$ August 2018

Accepted for Publication: $31^{\text {st }}$ August 2018 recent years it has also been diagnosed in patients without liver disease. SBP is commonly reported in patients of ascites due to cirrhosis of liver. But it is also reported in cases of ascites due to other causes like cardiac, nephrogenic, malignancy, hypoprotenaemia $[2,3,4,5]$. If untreated, spontaneous bacterial peritonitis could be a fatal complication in patients of ascites [6]. However, mortality rate in patients of spontaneous bacterial peritonitis has decreased during past few years due to greater awareness of possibility of occurrence of this condition in asymptomatic patient with ascites [7].

Also, establishment of sound criteria for diagnosis, improvement in culture techniques and prompt, effective antibiotic therapy has helped decrease the morality rate $[8,9]$. This work was undertaken in patients of ascites due to various causes to study the ascitic fluid biochemical parameters and causative micro-organisms in patients suffering from SBP. 


\section{Aim}

To evaluate association between biochemical parameters and microorganisms causing SBP in ascites patients.

\section{Materials and Methods}

This study was conducted in a tertiary care teaching hospital in Western Maharashtra. A prospective study was performed on 100 patients of ascites out of which 68 were males and 32 were females.

\section{Inclusion criteria}

- 100 patients of Transudative type of ascites were studied.

- Commonest causes of transudative ascites are -

- Cirrhosis of liver

- Cardiac ascites

- Hypoproteinaemia

- Nephrogenic ascites

\section{Exclusion criteria}

o Those with exudative ascites due to a known cause.

- Those with history of invasive procedures like paracentesisor surgery on abdomen in last two weeks.

o History of antibiotic treatment within last 3 weeks before admission.

o Suspected cases of perforated viscous or paracentesis or tuberculosis.

\section{Diagnostic Criteria}

Spontaneous bacterial peritonitis was diagnosed if

1. Ascitic fluid polymorphonuclear cell count was $>250$ cells/ $\mu \mathrm{L}$ along with positive ascitic fluid culture and there was no apparent local source of infection.

$$
\text { OR }
$$

2. If ascitic fluid culture was negative and polymorphonuclear cell count was $>500$ cells/ $\mu \mathrm{L}$ and no antibiotics were received in last three weeks, a diagnosis of culture negative neutrocytic ascites (CNNA) was made.

\section{OR}

3.If ascitic fluid culture was positive for a single organism and polymorphonuclear cell count $<250$ cells $/ \mu \mathrm{L}$.

After admission all patients were interviewed and detailed history and complete physical examination was performed.

All the patients were investigated in detail. The investigations included complete blood count, liver function tests, renal function tests, electrolytes, ascitic fluid Gram stain and culture. Other selected investigations were carried on as required basis. The results were collated, tabulated and subjected to statistical analysis.

\section{Results}

Though, Liver and renal dysfunction have no direct correlation with spontaneous bacterial peritonitis (SBP), increased serum bilirubin, decreased serum albumin, increased blood urea level and increased serum creatinine level are risk factors found to be associated with development of SBP in patients of ascites (Table 1).

Table-1: Laboratory parameters in SBP patients $(n=15)$.

\begin{tabular}{|c|c|c|}
\hline Parameters & No. of abnormalvalues & Percentage \\
\hline $\begin{array}{c}\text { Increased Leucocyte count } \\
(>11,000 \text { cells/cmm) }\end{array}$ & 09 & $60.0 \%$ \\
$($ Normal: $4000-11000$ cells/cmm) & 13 & $86.7 \%$ \\
\hline $\begin{array}{c}\text { Increased Serum Bilirubin } \\
(\text { Normal: 0 - } 1.1 \mathrm{mg} / \mathrm{dl})\end{array}$ & 11 & $73.4 \%$ \\
\hline $\begin{array}{c}\text { Decreased Serum Albumin } \\
(\text { Normal:3.5 - 5.0 gm/dl) }\end{array}$ & 07 & $46.7 \%$ \\
\hline $\begin{array}{c}\text { Increased Blood Urea Level } \\
(\text { Normal: 0 -40 mg/dl) }\end{array}$ & 06 & $40.0 \%$ \\
\hline $\begin{array}{c}\text { Increased Serum Creatinine } \\
(\text { Normal: } 0.5-1.7 \mathrm{mg} / \mathrm{dl})\end{array}$ & & \\
\hline
\end{tabular}


Table 2: Significance of Low Protein Value in ASCITIC Fluid in SBP Patients.

\begin{tabular}{|c|c|c|c|}
\hline $\begin{array}{c}\text { Ascitic fluid } \\
\text { protein value }\end{array}$ & Ascites with SBP & Ascites without SBP & Total \\
\hline$<\mathbf{1} \mathbf{~ g m} / \mathbf{d l}$ & $12(80 \%)$ & $11(12.94 \%)$ & $\mathbf{2 3}(\mathbf{2 3} \%)$ \\
\hline$>\mathbf{1} \mathbf{~ g m} / \mathbf{d l}$ & $03(20 \%)$ & $74(87.06 \%)$ & $\mathbf{7 7}(\mathbf{7 7 \%})$ \\
\hline Total & $\mathbf{1 5}(\mathbf{1 5} \%)$ & $\mathbf{8 5}(\mathbf{8 5} \%)$ & $\mathbf{1 0 0}(\mathbf{1 0 0} \%)$ \\
\hline
\end{tabular}

Twelve $(12,80 \%)$ patients of SBP had ascitic fluid protein value $<1 \mathrm{gm} / \mathrm{dl}$ and $9(60 \%)$ had ascitic fluid $\mathrm{pH}<7.30$. The low ascitic fluid protein values $(<1 \mathrm{gm} / \mathrm{dl})$ found in patients of spontaneous bacterial peritonitis are found to be statistically significant as compared to that in patients of ascites without spontaneous bacterial peritonitis using Chisquare test. Value of $\chi^{2}=32.37$ at $1 \mathrm{~d}$. f. $\mathrm{p}>0.01$, highly significant (Table 2 ).

Table-3: Significance of low ACITIC fluid $\mathrm{pH}$ value in sbp patients.

\begin{tabular}{|c|c|c|c|}
\hline Ascitic fluid pH & Ascites with SBP & Ascites without SBP & Total \\
\hline$<\mathbf{7 . 3 0}$ & $09(60 \%)$ & $04(4.7 \%)$ & $\mathbf{1 3}(\mathbf{1 3 . 0} \%)$ \\
\hline$>\mathbf{7 . 3 0}$ & $06(40 \%)$ & $81(95.3 \%)$ & $\mathbf{8 7}(\mathbf{8 7 . 0} \%)$ \\
\hline Total & $\mathbf{1 5}(\mathbf{1 5} \%)$ & $\mathbf{8 5}(\mathbf{8 5} \%)$ & $\mathbf{1 0 0}(\mathbf{1 0 0 . 0} \%)$ \\
\hline
\end{tabular}

The low ascitic fluid $\mathrm{pH}$ values $(<7.30)$ found in patients of SBP are found to be statistically significant as compared to that in patients of ascites without SBP using Chi-square test. Value of $\chi^{2}=30.98$ at $1 \mathrm{~d}$. f. $\mathrm{p}<0.01$, highly significant (Table 3).

Table-4: Significance of increased serum bilirubin level in SBP patients.

\begin{tabular}{|c|c|c|c|}
\hline $\begin{array}{c}\text { Serum bilirubinlevel } \\
(\mathbf{m g} / \mathbf{d l})\end{array}$ & Ascites with SBP & Ascites without SBP & Total \\
\hline$<\mathbf{3 . 2}$ & $02(13.34 \%)$ & $63(74.11 \%)$ & $\mathbf{6 5}(\mathbf{6 5 . 0} \%)$ \\
\hline$>\mathbf{3 . 2}$ & $13(86.66 \%)$ & $22(25.88 \%)$ & $\mathbf{3 5}(\mathbf{3 5 . 0} \%)$ \\
\hline Total & $\mathbf{1 5}(\mathbf{1 5 \%})$ & $\mathbf{8 5}(\mathbf{8 5} \%)$ & $\mathbf{1 0 0}(\mathbf{1 0 0} \%)$ \\
\hline
\end{tabular}

The increased serum bilirubin levels $(>3.2 \mathrm{mg} / \mathrm{dl}$ ) found in patients of spontaneous bacterial peritonitis are found to be statistically significant as compared to that in patients of ascites without spontaneous bacterial peritonitis using Chisquare test. Value of $\chi^{2}=20.71$ at 1 d. f. $p<0.01$, highly significant (Table 4).

Table-5: Ascitic fluid analysis in SBP patients.

\begin{tabular}{|c|c|c|}
\hline Parameters & No.of cases of SBP & Percentage (\%) \\
\hline Ascitic fluid $\mathrm{pH}<7.30$ & 09 & $\mathbf{6 0 . 0} \%$ \\
\hline Ascitic fluid polymorphonuclear cell count & & $100.0 \%$ \\
$>250$ cells/cmm & 15 & $80.0 \%$ \\
$>500$ cells/cmm & 12 & $80.0 \%$ \\
\hline Ascitic fluid proteins $<1$ gm/dl & 12 & $46.7 \%$ \\
\hline Ascitic fluid culture report Positive & 07 & $53.3 \%$ \\
\hline Negative & 08 & $6.7 \%$ \\
\hline Gram stain & 01 & $6 \%$ \\
\hline
\end{tabular}

All patients of SBP had ascitic fluid polymorphonuclear cell count $>250$ cells/ $\mu \mathrm{L}$ and majority had $>500$ cells $/ \mu \mathrm{L}$. Seven $(7,46.7 \%)$ patients were culture positive and 8 were culture negative. Gram staining was positive in one case (Table 5). 
Original Research Article

Table- 6: Microorganisms identified in ASCITIC fluid culture of SBP patients.

\begin{tabular}{|c|c|c|}
\hline Microorganism & No. of cases & Percentage (\%) \\
\hline E-Coli & 04 & $57.1 \%$ \\
\hline Pseudomonasaeruginosa & 01 & $14.3 \%$ \\
\hline Klebsiellapneumoniae & 01 & $14.3 \%$ \\
\hline Staphylococcusaureus & 01 & $14.3 \%$ \\
\hline
\end{tabular}

Commonest microorganism identified was E-Coli followed by Pseudomonas aeruginosa, Klebsiella pneumoniae and Staphylococcus aureus, one case each (Table 6).

\section{Discussion}

In haematological investigations, leucocytosis on the peripheral blood smear was seen in $9(60 \%)$ patients. Leucocytosis is probably due to septicaemia, which is seen in patients of SBP. Melvin P Weinstein reported in their study - 21(75\%), out of 28 patients of SBP had leucocytosis which is associated with increased mortality in these patients [10]. The liver function tests do not directly relate to spontaneous bacterial peritonitis but indicates severity of underlying liver disease. In our study $13(86.7 \%)$ patients (out of 15 ) had raised serum bilirubin.Derangements of renal function tests were also noticed in patients of SBP. Seven $(46.7 \%)$ patients had increased blood urea level and six $(40 \%)$ patients had increased serum creatinine levels (Table 1).

In our study $12(80 \%)$ patients out of 15 had ascitic fluid protein value $<1 \mathrm{gm} / \mathrm{dl}$. Comparing these values with that of protein values in patients of ascites without SBP, the incidence of low ascitic fluid protein value was found to be statistically significant using Chisquare test (Table 2). All the patients had ascitic fluid $\mathrm{pH}<7.50$ and $9(60 \%)$ had $\mathrm{pH}<7.30$. The low ascitic fluid $\mathrm{pH}$ values (i.e. < 7.30) in a patient of SBP are found to be statistically significant as compared to that in patients of ascites without SBP using Chi-square test (Table 3).

According to Guarner, Carlos et al (1999) ascitic fluid protein value $<1 \mathrm{gm} / \mathrm{dl}$ is a risk factor for development of SBP due to decreased opsonic activity [11]. The low protein concentration in ascitic fluid is also a predisposing factor for SBP, due to poor opsonic activity according to Jeffery J, Murphy M. In our study $12(80 \%)$ patients out of 15 had ascitic fluid protein value $<1 \mathrm{gm} / \mathrm{dl}$ (Table 5). According to Montserrat A, Ricard S et al low ascitic fluid opsonic activity and low ascitic fluid complement levels are independent predictors of SBP [12]. However, these tests could not be done as facility was not available at our level. Similarly; raised Granulocyte elastase levels may be helpful for diagnosis of SBP, according to a study by Casafont $\mathrm{F}$ et al. But it could not be tested at our level [13]. Serum ascites albumin gradient (Serum albumin concentration minus ascitic fluid albumin concentration) is wide $(>1.1 \mathrm{gm} / \mathrm{dl})$ in SBP. But wide $(>1.1$ $\mathrm{gm} / \mathrm{dl}$ ) serum ascites albumin gradient is also seen in massive hepatic metastasis, veno-occlusive disease, and congestive cardiac failure. It has no significant value in the diagnosis of SBP.

According to $\mathrm{J}$ Jeffery et al cirrhotic patients with ascites who have hyperbilirubinemia of more than 3.2 $\mathrm{mg} / \mathrm{dl}$ are particularly at high risk for development of SBP [1]. In our study, thirteen patients' serum bilirubin levels were above $3.2 \mathrm{mg} / \mathrm{dl}$. The increased serum bilirubin level ( $>3.2 \mathrm{mg} / \mathrm{dl}$ ) SBP patients is found to be statistically significant as compared to that in patients of ascites without SBP (Table 4) Huber M, Schwarz W et al also found that incidence of SBP was more in alcoholic cirrhotics [14].

In non-infected ascites, ascitic fluid $\mathrm{pH}=$ serum $\mathrm{pH}$. The metabolism of glucose in infected ascitic fluid generates acids, which consequently reduces $\mathrm{pH}$. According to Clergue J, Scemama $\mathrm{C}$ et al, ascitic fluid $\mathrm{pH}<7.31$ is indicative of SBP [15]. Measurement of ascitic fluid polymorphonuclear cell-count is important and rapid method in diagnosis of SBP while the culture report awaited. In our study all patients of SBP had ascitic fluid polymorphonuclear cell count greater than 250 cells $/ \mu \mathrm{L}$ and $12(80 \%)$ patients had greater than 500 cells $/ \mu \mathrm{L}$ (Table 5).

In our study of 15 cases of SBP, $8(53.3 \%)$ cases had culture negative neutrocytic ascites and 7 (46.7\%) were culture positive. In a study done by Runyon BA, 15 (15\%) out of 100 patients developed SBP including its variant culture negative neutrocytic ascites [16]. This incidence is comparable with that of previous studies. Marcelli, Nardecchia L et al in their study found 


\section{Original Research Article}

incidence of SBP about 11\% [17]. Albilos A et al, Almdal T P et al in their studies reported incidence of SBP above $15 \%[18,19]$. Amarapurkar DN et al studied 31 patients of SBP (26 males and 5 females) reported incidence of SBP about $22.5 \%$ which included SBP and its variant culture negative neutrocytic ascites [7]. Our results were comparable with these studies.

Our incidence of culture negative neutrocytic ascites is comparable to that reported by Amarapukar et al. In their study there were three cases of culture negative neutrocytic ascites out of seven cases of spontaneous bacterial peritonitis.

Microorganisms in the ascitic fluid can be diagnosed by Gram staining. In our study we found Gram positive cocci in one case $(6.7 \%)$ (Table 5).

Another study done by Jain AP, Sharatchandra L et al results were as follows - 22 out of 63 patients of cirrhosis had SBP, 18 (81\%) were culture positive and 4 (18.18\%) were culture negative [20].

Commonest organism being coagulase positive Staphylococcus aureus - 8 (44.44\%), followed by E-coli - $4(22.22 \%)$ and 4 had infection with more than oneorganisms. The organisms isolated in our study were Ecoli - 4 (57.1\%) followed by Pseudomonas aeruginosa, Klebsiella pneumoniae and Staphylococcus aureus in one (14.3\%) case each (Table 6).

\section{Conclusion}

Leucocytosis in blood (71.4\%), serum bilirubin level $>3.2 \mathrm{mg} / \mathrm{dl}(85.7 \%), \mathrm{pH}$ of ascitic fluid $<7.30(57.1 \%)$, ascitic fluid protein level $<1 \mathrm{gm} / \mathrm{dl}(71.4 \%)$, raised blood urea level $>40 \mathrm{mg} / \mathrm{dl}(57.1 \%)$, raised serum creatinine level $>1.7 \mathrm{mg} / \mathrm{dl}(42.85 \%)$ were the factors found to be associated with SBP in the patients of ascites. The commonest micro-organism identified on culture were E-coli

Hypoalbuminemia, hyperbilirubinemia, low ascitic fluid $\mathrm{pH}$, low ascitic fluid proteins, increased blood urea and creatinine levels are risk factors related with development of SBP in patients of ascites.

SBP should be suspected in any patient of ascites having fever, abdominal pain, altered sensorium, leuocytosis, hyper bilirubinemia, azotemia or neutrocyticascites. Early detection of SBP could be lifesaving.

Funding: Nil, Conflict of interest: None

Permission of IRB: Yes

\section{References}

1. Jeffery J, Murphy MJ. Ascitic fluid analysis: the role of biochemistry and haematology. Hosp Med. 2001 May; 62 (5):282-6.

2. Horn S, Holzer H, Horina JH. Spontaneous bacterial peritonitis in a patient with nephrogenic ascites during an episode of acute renal transplant rejection. Am J Kidney Dis. 1996 Mar;27(3):441-3.

3. Runyon BA. Spontaneous bacterial peritonitis associated with cardiac ascites. Am J Gastroenterol. 1984 Oct; 79(10):796.

4. Kurtz RC, Bronzo RL. Does spontaneous bacterial peritonitis occur in malignant ascites? Am J Gastroenterol. 1982 Mar;77(3):146-8.

5. Woolf GM, Runyon BA. Spontaneous Salmonella infection of high-protein noncirrhotic ascites. J Clin Gastroenterol. 1990 Aug;12(4):430-2.

6. Correia JP, Conn HO. Spontaneous bacterial peritonitis in cirrhosis: endemic or epidemic? Med Clin North Am. 1975 Jul; 59 (4):963-81.

7. Amarapurkar DN, Viswanathan N, Parikh SS, et al. Prevalence of spontaneous bacterial peritonitis. J Assoc Physicians India. 1992 Apr;40(4):236-8.

8. Conn HO, Fessel JM. Spontaneous bacterial peritonitis in cirrhosis: variations on a theme. Medicine (Baltimore). 1971 May; 50(3):161-97.

9. Conn ho. Spontaneous peritonitis and bacteremia in Laennec's cirrhosis caused by enteric organisms. A relatively common but rarely recognized syndrome. Ann Intern Med. 1964 Apr;60:568-80.

10. Weinstein MP, Iannini PB, Stratton CW, Eickh off TC. Spontaneous bacterial peritonitis. A review of 28 cases with emphasis on improved survival and factors influencing prognosis.Am J Med. 1978 Apr;64(4):592-8

11. Guarner Carlos, Ricard Solaet al: Risk factor of a first community-acquired Spontaneous Bacterial Peritonitis in cirrhotics with low ascitic protein level. Gastroenterology, 1999;117(2):414-19.

12. Andreu M, Sola R, Sitges-Serra A, et al. Risk factors for spontaneous bacterial peritonitis in cirrhotic patients with ascites. Gastroenterology. 1993 Apr;104 (4): 1133-8. 
Original Research Article

13. Casafont F, Rivero M, Fernandez MD, et al. Granulocyte elastase in cirrhotic patients with spontaneous bacterial peritonitis. Dig Dis Sci. 1999 Oct; 44 (10):1985-9.

14. Huber M, Schwarz W, Vogl T, Zeuzem S. [Clinical aspects of liver cirrhoses and its complications and diagnostic problems].Radiologe.2001Oct;41(10):840-51

15.Scemama-Clergue J, Doutrellot-Philippon C,Metreau JM, et al. Ascitic fluid $\mathrm{pH}$ in alcoholic cirrhosis: a reevaluation of its use in the diagnosis of spontaneous bacterial peritonitis. Gut. 1985 Apr;26(4):332-5.

16. Runyon BA, Hoefs JC. Ascitic fluid chemical analysis before, during and after spontaneous bacterial peritonitis. Hepatology. 1985 Mar-Apr;5(2):257-9.
17. Gençer S, Ozer S. Spontaneous bacterial peritonitis caused by Brucella melitensis. DOI:10.1080/ 00365 540310000238

18. Albillos A, Cuervas-Mons V, Millán I, et al. Ascitic fluid polymorphonuclear cell count and serum to ascites albumin gradient in the diagnosis of bacterial peritonitis. Gastroenterology. 1990 Jan; 98 (1):134-40.

19. Almdal TP, Skinhøj P. Spontaneous bacterial peritonitis in cirrhosis. Incidence, diagnosis, and prognosis. Scand J Gastroenterol. 1987 Apr;22(3):295-300.

20. Jain AP, Chandra LS, Gupta S, et al. Spontaneous bacterial peritonitis in liver cirrhosis with ascites. J Assoc Physicians India. 1999 Jun; 47 (6): 619-21.

\section{How to cite this article?}

Gadekar R, Tyagi A, Waran M, Srivastava AK. A study of biochemical parameters and microbial organisms in ascitic fluid of spontaneous bacterial peritonitis patients. Int J Med Res Rev 2018; 6(06): 315-320.doi: 10.17511/ijmrr. 2018. i06.04. 